\title{
HYGIENISATION OF SURPLUS ACTIVATED SLUDGE BY HYDRODYNAMIC CAVITATION
}

\author{
HIGIENIZACJA OSADU CZYNNEGO NADMIERNEGO \\ W PROCESIE KAWITACJI HYDRODYNAMICZNEJ
}

\begin{abstract}
The success of an effective process of disintegration is the application of physical or chemical methods of the destruction of the cell wall which consequently becomes fragmented and the intracellular matters are released into the surrounding liquid. The purpose of the conducted experiments was to demonstrate possibilities of application of the hydrodynamic in the bacteriological hygienisation of surplus activated sludge. The confirmation of the effectiveness of the bactericidal activity of hydrodynamic cavitation was the number of bacteria grown on agars before and after hygienisation process. Selective and basic beddings have been used in the research. The bacterial culture has lasted approximately 24 to 48 hours. After the period of incubation the colonies produced have been counted and initially identified. Based on the microbiological analyses a significant reduction in an overall number of bacteria and pathogenic bacteria belonging to the family Enterobacteriaceae and to the pathogenic species Staphylococcus has been noticed. The overall number of bacteria decrease about $80 \%$ after 45 minutes of disintegration of surplus activated sludge. Pathogenic bacteria belonging to the family Enterobacteriaceae: lactose-positive and lactose-negative decrease about $93 \%$ and $92 \%$, respectively. Reducing the number of Salmonella bacteria was $100 \%$ after 45 minutes of disintegration processes. Reduction bacteria of species Staphylococcus were about 93\% for mannitolo-positive and $92 \%$ for mannitolo-negative.
\end{abstract}

Keywords: disintegration of surplus activated sludge, hydrodynamic cavitation, hygienisation

The success of an effective process of disintegration is the application of physical or chemical methods of the destruction of the cell wall which consequently becomes fragmented and the intracellular matters are released into the surrounding liquid.

The product can be utilized both as a substrate in aerobic as well as anaerobic biological processes. The application of disintegration technology into the sludge treatment process leads to reduced sludge quantities and markedly improves sludge quality.

Several disintegration processes are developed: mechanical: hydrodynamic cavitation, ultrasound, homogenizer, stirred ball mills; thermal hydrolysis (autoclave or steam heating), wet oxidation; chemical: use of enzymes, alkaline/acid hydrolysis; biological: thermophilic aerobic/anaerobic pretreatment. These disintegration methods are common for activated

\footnotetext{
${ }^{1}$ Institute of Engineering and Environmental Protection, Faculty of Materials and Environmental Sciences, University of Bielsko-Biala, ul. Willowa 2, 43-309 Bielsko-Biała, Poland, phone +48 338279157

2 Śląskie Środowiskowe Studium Doktoranckie PAN, pl. Gwarków 1, 40-166 Katowice, Poland

*Corresponding author: kgrubel@ath.bielsko.pl
} 
sludge stabilization, resulting in solubilization of sludge volatile matter and the production of biogas [1]. Positive effects were shown for thermal pretreatment [2-4], addition of enzymes [5, 6], ozonation [7-9], chemical solubilization by acidification [10] or alkaline hydrolysis [11, 12], and mechanical and ultrasonic sludge disintegration [13-20]. One of the disintegration method is hydrodynamic cavitation. Hydrodynamic cavitation results in formation of cavities (bubbles) filled with a vapour - gas mixture inside the flowing liquid, or at the boundary of a constriction devices due to rapid local pressure drop. Subsequently, the pressure recovers down the constriction (valve or nozzle) and causes cavities to collapse. The collapse of cavitation bubbles is defined as implosion and the forces associated with results in mechanical and physicochemical effects. The physical effects include the production of shear forces, shock waves, generating local high temperatures and pressures, whereas the chemical effects result into the generation of radicals $e g$ formation of reactive hydrogen atoms and hydroxyl radicals which recombine to form hydrogen peroxide [21-23].

Although the methods of disintegration are different in character, they all aim to achieve partial or complete lysis of bacteria cells disintegration leads to reduced microorganisms quantities. The purpose of the conducted experiments was to demonstrate possibilities of application of the hydrodynamic disintegration in the bacteriological hygienisation of surplus activated sludge.

\section{Materials and methods}

\section{Material and experimental installation}

Surplus activated sludge samples were taken from an Enhanced Biological Nutrient Removal (EBNR) full scale municipal sewage treatment plant. The treatment plant was designed for the flow of $12000 \mathrm{~m}^{3} / \mathrm{d}$. For the time being, the amount of flowing sewage is ca $90000 \mathrm{~m}^{3} / \mathrm{d}$, sewage retention time ca 14 days and concentration of activated sludge in the bioreactor $4320 \div 4640 \mathrm{mg} / \mathrm{dm}^{3}$.

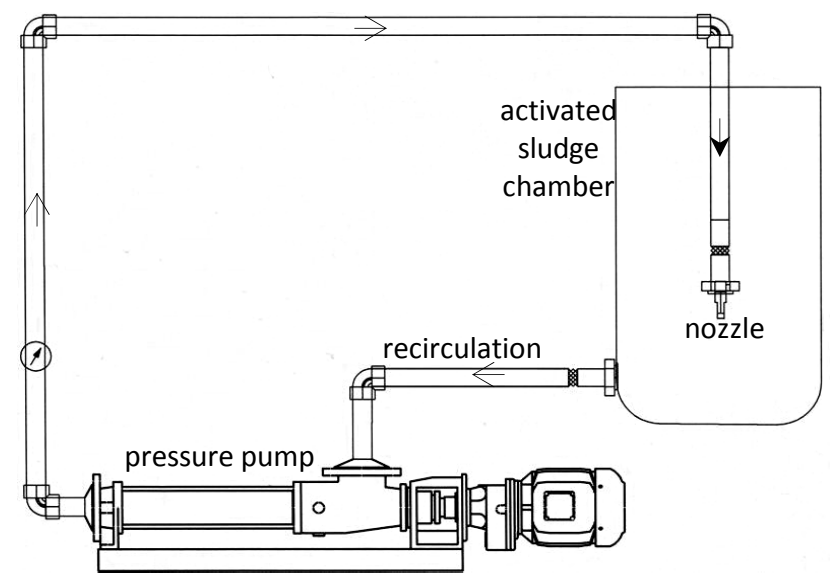

Fig. 1. Scheme of the experimental installation 
Hydrodynamic disintegration was executed with the application of a pressure pump (12 bar), which recirculated sludge from a $25 \mathrm{dm}^{3}$ container, through a constructed cavitation nozzle. The process was carried out for 15, 30 and 45 minutes. Scheme of the experimental installation is shown in Figure 1.

\section{Microbiological methods}

Selective and basic beddings have been used in the research. For cultivation methods of microorganisms the following mediums were used:

- Nutrient agar

- MacConkey agar

- Chapman agar

- Salmonella/Shigella agar (SS)

The bacterial cultures were incubated at $37^{\circ} \mathrm{C}$ and have lasted approximately 24 to 48 hours. After the period of incubation the colonies produced have been counted and initially identified.

For in vitro diagnosis of some bacteria, the API 20E tests (of BioMerieux) which are a semi-quantitative micromethod, serving for assessment of the enzymatic activity were used.

Surplus activated sludge samples characterized by a high abundance of bacteria. Therefore, before plating was performed dilutions of the test material from $10^{-1}$ to $10^{-10}$. The investigations presented here were performed 5 times in 5 stages.

The number of bacteria in $1 \mathrm{~cm}^{3}$ of surplus activated sludge was calculated according to PN-EN ISO 6222:2004.

\section{Results and discussion}

The confirmation of the effectiveness of the bactericidal activity of hydrodynamic cavitation was the number of bacteria grown on agars before and after hygienisation process.

According to the methodology used, the process of hydrodynamic disintegration was carried out for 15,30 and 45 minutes. The prolonged time of hygienisation by hydrodynamic disintegration results in a decrease of overall number of bacteria. After 45 minutes disruption of bacteria the quantity decrease of $80 \%$ (Fig. 2).

The use of hydrodynamic cavitation for the bacterial indicator of sanitary assessment of sewage sludge showed the devastating effects and decrease number bacteria of the genus Salmonella. Reducing the number of Salmonella bacteria was $100 \%$ after 45 minutes of disintegration processes (Fig. 3). Cavitation has also resulted in the reduction of Shigella sp. sticks by $96 \%$ (Fig. 3).

Hydrodynamic cavitation caused reduction of pathogenic bacteria belonging to the family Enterobacteriaceae: lactose-positive and lactose-negative decrease about $93 \%$ and $92 \%$, respectively (Fig. 4).

Hygienisation process has also contributed to the reduction of bacteria of the genus Staphylococcus, those pathogenic for humans (mannitolo-positive) and non-pathogenic (mannitolo-negative). Reducing the number of Staphylococcus mannitolo-positive and mannitolo-negative after 45 minutes of disintegration processes was $93 \%$ and $92 \%$, respectively (Fig. 5). 


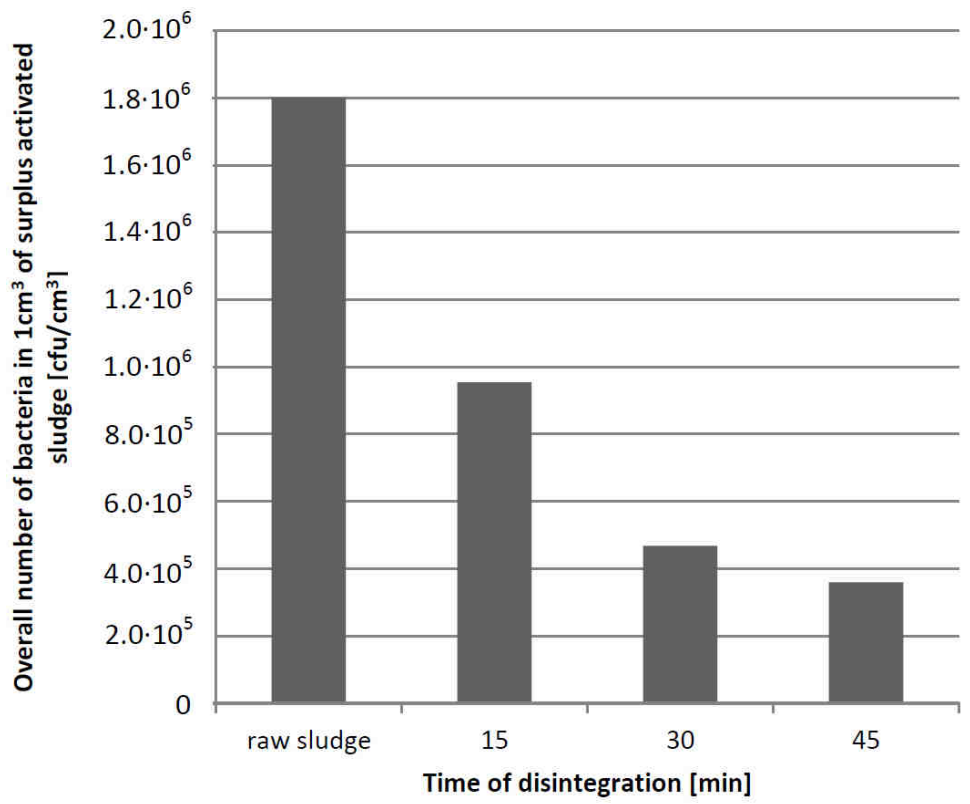

Fig. 2. Overall number of bacteria in $1 \mathrm{~cm}^{3}$ of surplus activated sludge before and after hygienisation process

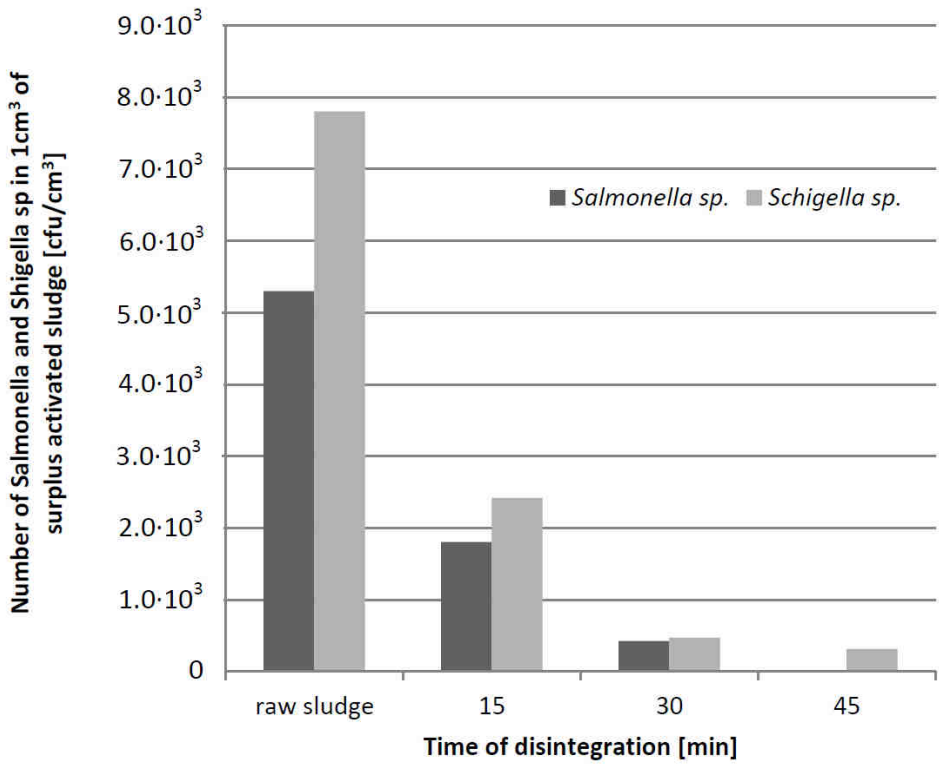

Fig. 3. Number of Salmonella and Shigella sp. in $1 \mathrm{~cm}^{3}$ of surplus activated sludge before and after hygienisation process 


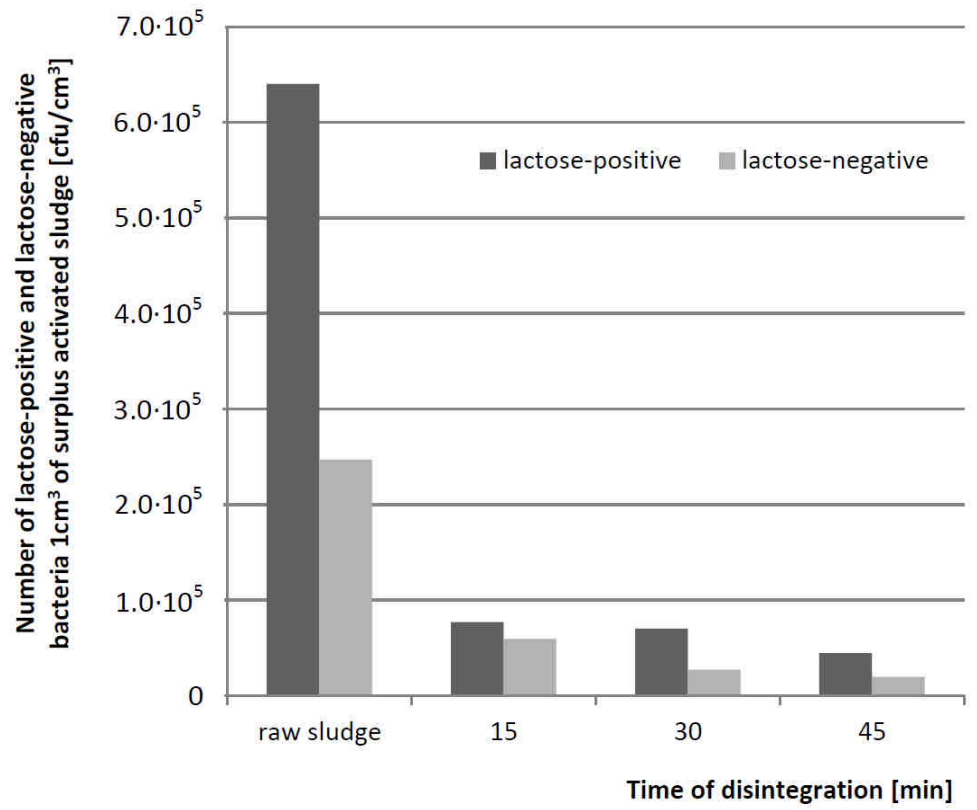

Fig. 4. Number of lactose-positive and lactose-negative bacteria $1 \mathrm{~cm}^{3}$ of surplus activated sludge before and after hygienisation process

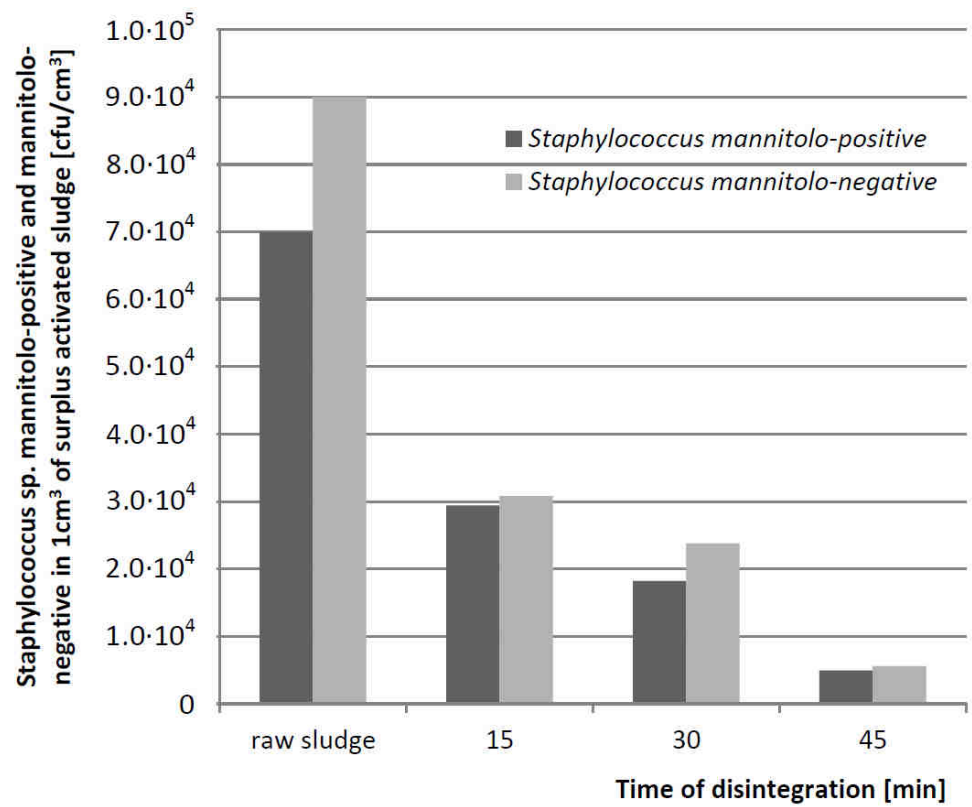

Fig. 5. Number of Staphylococcus sp. mannitolo-positive and mannitolo-negative in $1 \mathrm{~cm}^{3}$ of surplus activated sludge before and after hygienisation process 
The effect of cell disruption (hygienisation process) depends on time of disintegration, environment, age, type and form of microorganisms (vegetative form, spores) and age of the culture. The death of bacteria by lysis of cells under the influence of hydrodynamic cavitation is a function of logarithmic time of them actions. Generally, the more vulnerable are young cultures, but each organism has a different sensitivity associated with the duration of action. There are, in fact significant differences in sensitivity between the types of organisms and even different species within the genera.

\section{Conclusions}

Based on the microbiological analyses a significant reduction in an overall number of bacteria and pathogenic bacteria belonging to the family Enterobacteriaceae and to the pathogenic species Staphylococcus has been noticed. The overall number of bacteria decrease about $80 \%$ after 45 minutes of disintegration of surplus activated sludge. Pathogenic bacteria belonging to the family Enterobacteriaceae: lactose-positive and lactose-negative decrease about $93 \%$ and $92 \%$, respectively. Reducing the number of Salmonella bacteria was $100 \%$ after 45 minutes of disintegration processes. Reduction bacteria of species Staphylococcus were about $93 \%$ for mannitolo-positive and $92 \%$ for mannitolo-negative.

\section{References}

[1] Appels L, Bayenes J, Degrève J, Dewil R. Prog Energy Comb Sci. 2008;34:755-781. DOI: 10.1016/j.pecs.2008.06.002

[2] Camacho P, Ginestet P, Audic JM. Water Sci Technol. 2005;10-11:235-245.

[3] Kepp U, Machenbach I, Weisz N, Solheim OE. Water Sci Technol. 2000;42:89-96.

[4] Phothilangka P, Schoen MA, Huber M, Luchetta P, Winkler T, Wett B. Water Sci Technol. 2008;58: 1467-1473.

[5] Barjenbruch M, Kopplow O. Adv Environ Res. 2003;7:715-720. DOI: 10.1016/S1093-0191(02)00032-1.

[6] Roman HJ, Burgess JE, Pletschke BI. Afr J Biotechnol. 2006; 5: 963-967.

[7] Carballa M, Manterola G, Larrea L, Ternes T, Omil F, Lema JM. Chemosphere 2007;67:1444-1452. DOI: 10.1016/j.chrmosphere.2006.10.004.

[8] Song KG, Choung YK, Ahtf KH, Cho J, Yun H. Desalination 2003;157:353-359.

[9] Weemaes M, Grootaerd H, Simoens F, Verstraete W. Water Res. 2000, 34, 2330-2336. DOI: 10.1016/S0043-1354(99)00373-5.

[10] Woodard SE, Wukasch RF. Water Sci Technol. 1994;30,29-38.

[11] Mukherjee SR, Levine AD. Water Sci Technol. 1992;26,2289-2292.

[12] Vlyssides AG, Karlis PK. Biores Technol. 2004;91:201-206.

[13] Antoniadis A, Poulios I, Nikolakaki E, Mantzavinos D. J Hazard Mater. 2007;146:492-495. DOI: $10.1016 /$ j.jhazmat.2007.04.065

[14] Kampas P, Parsons SA, Pearce P, Ledoux S, Vale P, Churchley J, Cartmell E. Water Res. 2007;41:1734-1742. DOI: 10.1016/j.watres.2006.12.044

[15] Kennedy KJ, Thibault G, Droste RL. Water SA 2007;33:261-270.

[16] Müller J, Lehne G, Schwedes J, Battenberg S, Näveke R, Kopp J, Dichtl N. Water Sci Technol. 1998;38:425-433.

[17] Müller J. Water Sci Technol. 2000;41:123-139.

[18] Wang F, Lu S, Ji M. Ultra Sonochem. 2006;13:334-338. DOI:10.1016/j.ultsonch.2005.04.008.

[19] Zhang G, Zhang P, Yang J, Chena Y. J Hazard Mater. 2007;145:515-519. DOI: 10.1016/j.jhazmat.2007.01.133

[20] Zhang P, Zhang G, Wang W. Bioresource Technol. 2007;98:207-210. DOI: 10.1016/j.biortech.2005.12.002.

[21] Dewil R, Baeyens J, Goutvrind R. Environ Prog. 2006;25:121-128.

[22] Vichare NP, Gogate PR, Pandit AB. Chem Eng Technol. 2000;23:683-690. DOI: 10.1002/1521-4125(200008)23:8. 
[23] Senthilkumar P, Sivakumar M, Pandit AB. Chem Eng Sci. 2000;55:1633-1639. DOI: 10.1016/S0009-2509(99)00435-2.

\title{
HIGIENIZACJA OSADU CZYNNEGO NADMIERNEGO W PROCESIE KAWITACJI HYDRODYNAMICZNEJ
}

\author{
Instytut Ochrony i Inżynierii Środowiska, Wydział Nauk o Materiałach i Środowisku \\ Akademia Techniczno-Humanistyczna, Bielsko-Biała
}

\begin{abstract}
Abstrakt: Skuteczność procesu dezintegracji wynika z fizycznych lub chemicznych metod destrukcji ściany komórkowej, co w konsekwencji prowadzi do jej fragmentacji i uwalniania wewnątrzkomórkowych substancji do otaczającej fazy płynnej. Celem przeprowadzonych badań było wykazanie możliwości zastosowania kawitacji hydrodynamicznej do bakteriologicznej higienizacji osadu czynnego nadmiernego. Potwierdzeniem skuteczności bakteriobójczego działania kawitacji hydrodynamicznej była liczba bakterii rosnących na agarach przed i po procesie higienizacji. Do badań użyto podłoży podstawowych i selektywnych. Hodowla kultur bakteryjnych trwała 24 i 48 godzin. Po czasie inkubacji kultury zostały policzone i poddane wstępnej identyfikacji. Na podstawie przeprowadzonych analiz stwierdzono redukcję ogólnej liczby bakterii o ok. $80 \%$ po 45 minutach dezintegracji osadu czynnego nadmiernego. Patogenne bakterie należące do rodziny Enterobacteriaceae uległy redukcji: laktozo-dodatnie o ok. 93\%, a laktozo-ujemne o ok. 92\%. Bakterie z rodzaju Salmonella uległy całkowitemu zniszczeniu. Liczba bakterii z rodzaju Staphylococcus zmniejszyła się o $93 \%$ w przypadku mannitolo-dodatnich i o $92 \%$ w przypadku mannitolo-ujemnych.
\end{abstract}

Słowa kluczowe: dezintegracja osadu czynnego nadmiernego, kawitacja hydrodynamiczna, higienizacja osadu 